\title{
Data challenges in the measurement of agricultural productivity: Lessons from Chile
}

\author{
Boris E. Bravo-Ureta ${ }^{1,2}$, Roberto Jara-Rojas ${ }^{2,3}$, Víctor H. Moreira López ${ }^{4}$, \\ and Patricio Riveros Villegas ${ }^{5}$ \\ 'University of Connecticut (UConn), Agricultural and Resource Economics, Storrs, CT, 06268, USA. \\ ${ }^{2}$ Universidad de Talca, Department of Agricultural Economics. Chile \\ ${ }^{3}$ Núcleo Milenio CESIEP, Chile. \\ ${ }^{4}$ Universidad Austral de Chile, Department of Agricultural Economics. Chile \\ ${ }^{5}$ Universidad de Chile, Department of Economics. Chile
}

\begin{abstract}
B.E. Bravo-Ureta, R. Jara-Rojas, V.H. Moreira López, and P. Riveros Villegas. 2021. Data challenges in the measurement of agricultural productivity: Lessons from Chile. Int. J. Agric. Nat. Resour. 126-148. Productivity measurement and analysis have motivated considerable theoretical and empirical work in recent decades. Models that have enjoyed noticeable expansion are stochastic production frontiers for panel data. These models have proven very useful in total factor productivity (TFP) measurement and the analyses of its components. However, the related empirical literature in Latin America and the Caribbean has been limited, and a likely reason for this gap is data constraints. This article examines the setting surrounding the measurement and analysis of productivity in the Chilean agricultural sector. The specific objectives are to (1) provide a summary of key agricultural productivity measures and recent associated methodological advances; (2) present an overview of micro studies reporting technical efficiency and TFP in Chile; (3) portray the major sources of agricultural data available in the country; and (4) discuss salient features of the agricultural data systems used in Australia and the United States. The paper ends by identifying challenges and possible improvements to the prevailing data system that could strengthen the measurements and monitoring of productivity in Chile. The analysis suggests that the country needs substantial improvements in the collection and analysis of agricultural statistics to develop TFP and related research. This line of work is a critical step to enhance competitiveness and to foster adaptations to climate change, as well as to fully participate in efforts sponsored by the IFAD, FAO and the OECD to monitor progress toward the SDGs. On the positive side, several avenues are available to move toward a more robust agricultural statistical architecture.
\end{abstract}

Keywords: Agricultural data system, Chile, technical efficiency, total factor productivity.

\footnotetext{
Abbreviations used: SIP (single input productivity); TFP (total factor productivity); SPF (stochastic production frontier); DEA (data envelopment analysis); TE (technical efficiency); SDGs (Sustainable Development Goals).
}

Received Jan 27, 2021. Accepted Dic 16, 2021

Corresponding author: boris.bravoureta@uconn.edu; rjara@utalca.cl 


\section{Introduction}

Productivity growth is a necessary condition for enhancing competitiveness in an increasingly globalized economy. Such growth is also the foundation for farm prosperity and is critical for reducing poverty, enhancing food security and deepening the participation of the agricultural sector in international trade (FAO, 2015; World Bank, 2008). Moreover, the serious challenges imposed by climate change and the degradation of the natural resource base in many regions around the globe are serious considerations, as policymakers seek to increase agricultural productivity. Additional pressure arises from the need to feed a population that continues to grow along with rising incomes. The combined effect of income and population growth is expected to be a doubling in the demand for agricultural products over the next 50 years, which will necessitate substantial increases in agricultural productivity (Fuglie et al., 2020).

The critical role that agriculture plays in developing countries and the commitment from the international community to combat poverty, reflected in the Millennium Development Agenda (UN, 2016) and more recently the Sustainable Development Goals (SDGs) (UN, 2020), provide another impetus for accelerating the measurement and analysis of farm productivity growth (GSARS, 2018). For example, Target 2.3 of SDG 2 indicates that the goal by 2030 is to "...double the agricultural productivity and incomes of small scale-food producers...", while Target 2.4 states the need to "...ensure sustainable food production systems and implement resilient agricultural practices that increase productivity and production..." (UN, 2016, p. 11). Elaborate procedures have been set forth to construct the indicators required to document progress toward these and many other SDG targets, and this effort seeks to make these measures comparable across countries (FAO, 2020).

Major methodological innovations have been introduced in the past few decades that make it possible to conduct informative productivity analysis (Fried, Lovell, \& Schmidt, 2008; GSARS, 2017; O’Donnell, 2018; Sickles \& Zelenyuk, 2019). A crucial requirement, in addition to sound methodologies, for the estimation of models and making the calculations necessary to perform robust productivity analysis and implement sound policies is to have high-quality data. Unfortunately, suitable data are not available in many countries, particularly in the developing world (GSARS, 2018).

The general objective of this article is to examine the setting regarding the measurement and analysis of productivity in Chile's agricultural sector. To achieve this overall goal, this paper pursues the following four specific objectives: (1) provide a summary of key agricultural productivity measures and recent associated methodological advances; (2) present an overview of studies reporting technical efficiency and total factor productivity in Chile; (3) portray the major sources of agricultural data available in the country; and (4) discuss salient features of the agricultural data systems used in Australia and the United States. The paper contributes to ongoing efforts seeking to ascertain avenues to improve the prevailing agricultural statistical base with the intention of strengthening the measurement, analysis and monitoring of farm productivity in Chile.

The next four sections of the paper deal sequentially with each of the four objectives. The last section highlights challenges and offers recommendations that could reduce the information gaps identified in the context of ongoing international efforts at data collection and analysis.

\section{Overview of productivity concepts and some methods}

Productivity measurement and analysis has motivated a wide spectrum of theoretical and empirical work in economics over the past century. In recent decades, there has been robust renewed interest in the study of productivity in general and in the 
agricultural sector in particular (Christensen, 1975; Fried, Lovell, \& Schmidt, 2008; GSARS, 2017; World Bank, 2008).

The most basic productivity measure is single input productivity (SIP), and a classic example in agriculture is yield, i.e., total production divided by total area (e.g., tons of wheat per ha). SIP indicators are frequently used because they are simple to calculate and understand, but a serious limitation is that all other factors of production are ignored (Headey, Alauddin, \& Rao, 2010; Morrison Paul, 1999). Recognizing the value and limitations of SIP measures, Njuki and Bravo-Ureta (2019) introduced an SIP approach incorporating multiple inputs while accounting for unobserved heterogeneity with the purpose of providing a simple productivity measure while in the background accounting for the complexities of the production environment. To more directly tackle the deficiencies of SIP measures, total factor productivity (TFP) indicators have been developed and are currently widely used in economic analysis (Coelli et al., 2005). TFP is given by the ratio between aggregate output to aggregate inputs, and such a ratio can be calculated in a number of different ways. TFP has become widely used to examine productivity change across space and time and to decompose such changes into various elements. A detailed discussion can be found in Sickles and Zelenyuk (2019) and O'Donnell (2018), while examples of recent applications to agriculture include Njuki, Bravo-Ureta and Cabrera (2020) and Julien, Bravo-Ureta and Rada (2019).

TFP change (TFPC) represents the rate of change of the ratio of outputs over inputs, which can be separated into various components, including technical efficiency (TE), allocative efficiency, scale efficiency, environmental effects and technological change (Coelli et al., 2005). TFPC arises when products grow at a different rate (higher or lower) than inputs, and two central questions emerge: 1) How can these changes be quantified? and 2) What are the sources of these productivity changes? (Kumbhakar \& Lovell,
2000). The first question can be addressed using index numbers, and various options are available (Coelli et al., 2005). The calculation of index numbers does not require econometric estimation and is based on quantity and price data for inputs and outputs and assumptions about the technology and behavior. The first question can also be answered by estimating stochastic production frontiers (SPFs) or by applying nonparametric methods, such as data envelopment analysis (DEA). SPFs and DEA have the advantage of not requiring detailed price information or behavioral assumptions (GSARS, 2018; Kumbhakar \& Lovell, 2000). Turning to the second question, index number methods cannot disentangle the sources of TFPC, while SPF and DEA approaches are well suited to do so. Moreover, recent SPF methods are able to account for unobserved heterogeneity and specification errors while identifying transient and persistent TE separately (Filippini \& Greene, 2016). Recent applications include Njuki, BravoUreta and Cabrera (2020), Njuki, Bravo-Ureta and O'Donnell (2018), and O'Donnell (2016).

We now turn to a brief discussion of SPF models. We emphasize the SPF approach because it is consistent with the neoclassical notion of optimizing (i.e., maximizing, minimizing) underscoring the definitions of production, revenues, benefits, and cost functions. Another reason is the major recent refinements in the SPF methodology along with the ability to attribute TFPC to several components, especially when panel data are available. Nishimizu and Page (1982), forerunners in TFP decomposition, noted that technological progress and TE were concepts grounded on the production function model, but the associated empirical work had proceeded along separate paths. These authors estimated a deterministic parametric production frontier following the linear programming approach developed by Aigner and Chu (1968) and incorporated technological progress along with TE as sources of productivity change. The decomposition approach introduced by Nishimizu and Page (1982) was later incorporated within 
a stochastic framework by Ahmad and BravoUreta (1995). More recent work has expanded the components of TFPC to scale and allocative efficiency, environmental, agroecological and/or climatic conditions where different firms operate, and a statistical term that captures functional form and related errors (Kumbhakar \& Lovell, 2000; O’Donnell, 2016).

Identifying and quantifying the distinct components that underscore TFP is important for managerial decisions and public policy formulation seeking to enhance performance (Fried, Lovell, \& Schmidt, 2008). For example, TE refers to the distance of a firm's operation from the frontier and is a measure of management effort or performance, which in turn is associated with improvements in human capital achievable chiefly through education, training and experience (Martin \& Page, 1983; Triebs \& Kumbhakar, 2018). In contrast, technological progress reflects jumps or shifts in the production frontier stemming from innovations resulting from investments in research and development, or R\&D (Färe, Grosskopf, \& Margaritis, 2008).

Before closing this section, it is important to state that TFP analyses of multi-input multioutput technologies, particularly when using econometric procedures, require aggregation. This aggregation necessitates the use of weights for individual inputs and outputs to derive the respective aggregate indices. The procedures employed for these aggregations are a critical and controversial part of TFP work, but this matter is outside the scope of this paper. The interested reader can find in-depth discussions on these issues in O'Donnell (2018) and Sickles and Zelenyuk (2019) and in many references cited by these authors.

\section{Empirical productivity measures for Chilean agriculture}

In this section, we present evidence for Chilean agriculture concerning two critical measures of productivity, technical efficiency (Table 1) and total factor productivity growth (Table 2), that have been presented in the literature over the past few decades. The starting point in collecting the papers analyzed is the database developed by Bravo-Ureta et al. (2017). To complement these papers, we carried out a new search at the end of 2020 using the following databases: EBSCOhost, Econlit, Academic Search Premier, Agricola, Scopus and Wiley Online Library. The terms used in this recent search were Chile, TE, farming, agriculture, productivity, and TFP.

\section{Technical Efficiency (TE)}

As noted above, TE is a proxy measure for managerial performance, which is typically calculated as the ratio between observed output and the maximum output achievable by the best performing farms in a sample given inputs, technology, and the environment. Table 1 shows the results from 15 studies, organized in chronological order according to year of publication, that report TE measures for Chilean agriculture using farmlevel data. We note that these studies include not only peer-reviewed publications but also several unpublished studies.

The first study is by Rivas (1996), which is based on two cross-sections, one for 1965-1966 and the other for 1970-1971. Ten years later, Moreira et al. (2006) and Santos, Foster and Ramírez (2006) reported TE measures for dairy and potato farms, respectively. For the 11-year period from 2009 to 2020, we found 12 studies, revealing some modest growth in this literature. Of these 12 papers, 11 were published in peer-reviewed journals. The average TE scores from all 15 studies ranged from $50 \%$ to $94.1 \%$.

A salient feature of the studies in Table 1 is the heavy dependence on cross-sectional data, observed in 11 out of the 15 studies. Moreover, three of the four panel studies rely on the same dataset. Therefore, the available farm data, particularly 
Table 1. Technical efficiency (TE) scores from Chilean farm-level data.

\begin{tabular}{|c|c|c|c|c|c|c|c|}
\hline 1rst Author year & Region/Area & Product & Frontier study & Data structure & $\begin{array}{l}\text { No. } \\
\text { Obs }\end{array}$ & Data year & TE avg \\
\hline $\begin{array}{l}\text { Rivas } \\
(1996)\end{array}$ & Chile & Value of output & Stochastic & $\begin{array}{l}\text { Cross section } \\
\text { ( } 2 \text { rounds) }\end{array}$ & $\begin{array}{l}105 \\
105\end{array}$ & $\begin{array}{l}1965 / 1966 \\
1970 / 1971\end{array}$ & $\begin{array}{l}65.8 \\
64.6\end{array}$ \\
\hline Moreira (2006) & Paillaco & Dairy & Stochastic & Panel data & 92 & $\begin{array}{l}1996 / 1997 \\
1998 / 2002\end{array}$ & $\begin{array}{l}77.0 \\
72.0\end{array}$ \\
\hline Santos (2006) & San Javier & Potatoes & Stochastic & Cross-section & 118 & 2003 & 73.7 \\
\hline $\begin{array}{l}\text { Moreira } \\
(2009)\end{array}$ & Paillaco & Dairy & Stochastic & Panel data & 92 & $\begin{array}{l}1996 / 1997 \\
1998 / 2002\end{array}$ & 72.2 \\
\hline $\begin{array}{l}\text { Moreira } \\
(2010)\end{array}$ & $\begin{array}{c}\text { Paillaco, Chile, } \\
\text { Argentina, and } \\
\text { Uruguay }\end{array}$ & Dairy & Stochastic & Panel data & 48 & $\begin{array}{l}1996 / 1997 \\
1998 / 2002\end{array}$ & 84.9 \\
\hline Jaime (2011) & Biobío & Wheat & Stochastic & Cross section & 5,580 & $2006 / 07$ & 61.0 \\
\hline Jaime (2011) & Ñuble & Wheat & Stochastic & Cross section & 167 & N/A & 50.0 \\
\hline Moreira (2011) & Central zone & Wine grapes & Stochastic & Cross section & 263 & $2005 / 06$ & 77.2 \\
\hline Veloso (2015) & Ñuble & Cattle & Stochastic & Cross section & 83 & $2007 / 08$ & 79.5 \\
\hline $\begin{array}{l}\text { von Cramon- } \\
\text { Taubadel (2014) }\end{array}$ & Chile & Value of output & Stochastic & Cross section & $\begin{array}{l}109 \\
342\end{array}$ & 2004 & $\begin{array}{l}89.0 \\
78.0\end{array}$ \\
\hline Moreira (2016) & $\begin{array}{l}\text { Biobío Region to } \\
\text { Los Lagos }\end{array}$ & Dairy & Stochastic & Panel data & 1,426 & 2005 to 2010 & 91.0 \\
\hline Riveros (2016) & $\begin{array}{l}\text { Chile } \\
\text { Central }\end{array}$ & $\begin{array}{l}\text { Value of Fruit } \\
\text { Output }\end{array}$ & Stochastic & Cross section & 9,657 & $\begin{array}{l}2013 \\
2014 \\
2015\end{array}$ & 59.9 \\
\hline Roco (2017) & $\begin{array}{l}\text { Chile } \\
\text { Central }\end{array}$ & Annual crops & Stochastic & Cross section & 274 & 2011 & $\begin{array}{l}67.8 \\
76.4 \\
72.3\end{array}$ \\
\hline Jara-Rojas (2018) & Maule & Raspberry & Stochastic & Cross section & 139 & 2011 & 81.0 \\
\hline $\begin{array}{l}\text { Bravo-Ureta } \\
(2020)\end{array}$ & $\begin{array}{l}\text { Different valleys, } \\
\text { central zone }\end{array}$ & Wine grapes & Stochastic & Cross section & 263 & $2005 / 06$ & $\begin{array}{l}72.4 \\
79.7 \\
94.1 \\
85.9\end{array}$ \\
\hline
\end{tabular}

panel data, are limited. A clear advantage of panel data is that they enable more robust econometric estimates and much richer productivity analyses (Bravo-Ureta et al., 2007; Coelli et al., 2005).

\section{Total Factor Productivity (TFP)}

The search for TFP studies with data from Chile was carried out, including works in English and Spanish. This search yielded 24 studies in total, 20 written in English and four in Spanish, and the majority were formal publications in journals. Most of the studies (20 of 24) use aggregate (macro) country-level data from the FAO, in some cases supplemented with other national sources. Four studies use only data for
Chile: two consider agriculture as a whole, the third examines agriculture, forestry and fisheries, and the fourth analyzes dairy farms and is the only one that uses farm-level data. Most of the older studies use accounting methods along with Malmquist or Törnqvist indices, and more recent studies rely on production frontiers.

Table 2 presents salient features for the 24 TFP studies found, and here, we summarize the TFPC measures provided for Chile. Olavarría, Bravo-Ureta and Cocchi (2004) were the first to analyze TFP focusing only on Chile. Using different aggregate databases (FAO, Central Bank and ODEPA) and Törnqvist indices, these authors report a $2.78 \%$ average annual agricultural TFPC for the period 1961-1996. Vergara and Rivero (2006), offering 
Table 2. Total Factor Productivity (TFP) measures for Chilean agriculture.

\begin{tabular}{|c|c|c|c|c|c|c|}
\hline $\begin{array}{l}\text { Author (s) publication } \\
\text { year }\end{array}$ & $\begin{array}{l}\text { Data (total } \\
\text { countries) }\end{array}$ & Source & Product & Annual TFPC & Method & Data year \\
\hline $\begin{array}{l}\text { Fulginiti and Perrin } \\
\text { (1997) }\end{array}$ & $\begin{array}{l}\text { Chile } \\
\text { (18 LIC) }\end{array}$ & FAO and others & Agriculture & $1.10 \%$ & $\begin{array}{l}\text { Non-parametric } \\
\text { Malmquist index }\end{array}$ & 1961-1985 \\
\hline Arnade (1998) & $\begin{array}{c}\text { Chile } \\
\text { (70 countries) }\end{array}$ & USDA, FAO & Agriculture & $1.25 \%$ & $\begin{array}{l}\text { Non-parametric } \\
\text { Malmquist index }\end{array}$ & $1961-1993$ \\
\hline $\begin{array}{l}\text { Fulginiti and Perrin } \\
\text { (1998) }\end{array}$ & $\begin{array}{l}\text { Chile } \\
\text { (18 LIC) }\end{array}$ & FAO and others & Agriculture & $1.1 \%$ & $\begin{array}{l}\text { Non-parametric } \\
\text { Malmquist index } \\
\text { CD variable coeff. } \\
\text { CD conventional }\end{array}$ & $1961-1985$ \\
\hline $\begin{array}{l}\text { Martin and Mitra } \\
\text { (2001) }\end{array}$ & $\begin{array}{c}\text { Chile } \\
(50 \text { countries })\end{array}$ & FAO and others & Agriculture & $\begin{array}{l}2.70 \% \\
2.73 \%\end{array}$ & $\begin{array}{c}\text { Translog } \\
\text { Cobb-Douglas }\end{array}$ & $1967-1992$ \\
\hline $\begin{array}{l}\text { Nin, Arndt and } \\
\text { Preckel (2003) }\end{array}$ & $\begin{array}{l}\text { Chile } \\
\text { (20 LIC) }\end{array}$ & FAO & Agriculture & $0.6 \%$ & $\begin{array}{l}\text { Non-parametric } \\
\text { Malmquist index }\end{array}$ & 1961-1994 \\
\hline Nin et al. (2003) & $\begin{array}{l}\text { Chile } \\
\text { (9 LIC and } \\
23 \mathrm{MIC})\end{array}$ & FAO & $\begin{array}{l}\text { Agriculture } \\
\text { Cattle } \\
\text { Crops }\end{array}$ & $\begin{array}{l}0.87 \% \\
0.82 \% \\
2.25 \%\end{array}$ & $\begin{array}{l}\text { Malmquist index } \\
\text { Distance function }\end{array}$ & 1965-1994 \\
\hline $\begin{array}{l}\text { Trueblood and } \\
\text { Coggins (2003) }\end{array}$ & $\begin{array}{c}\text { Chile } \\
\text { (115 countries) }\end{array}$ & FAO and others & Agriculture & $1.39 \%$ & Malmquist index & 1961-1991 \\
\hline $\begin{array}{l}\text { Bravo-Ortega and } \\
\text { Lederman (2004) }\end{array}$ & $\begin{array}{c}\text { Chile } \\
\text { (77 countries) }\end{array}$ & FAOSTAT 2002 & Agriculture & $1.2 \%$ & $\begin{array}{l}\text { Translog production } \\
\text { function }\end{array}$ & $1960-1997$ \\
\hline $\begin{array}{l}\text { Olavarría, Bravo- } \\
\text { Ureta and Cocchi } \\
\text { (2004) }\end{array}$ & Chile & $\begin{array}{l}\text { FAO, Central } \\
\text { Bank, ODEPA }\end{array}$ & Agriculture & $2.78 \%$ & Törnqvist Index & 1961-1996 \\
\hline $\begin{array}{l}\text { Rao and Coelli } \\
(2004)\end{array}$ & $\begin{array}{c}\text { Chile } \\
\text { (97 countries) }\end{array}$ & FAO & Agriculture & $1.90 \%$ & $\begin{array}{l}\text { Non-parametric } \\
\text { Malmquist index }\end{array}$ & 1980-1995 \\
\hline $\begin{array}{l}\text { Coelli and Rao } \\
(2005)\end{array}$ & $\begin{array}{c}\text { Chile } \\
\text { (93 countries) }\end{array}$ & FAO & Agriculture & $1.10 \%$ & $\begin{array}{l}\text { Non-parametric } \\
\text { Malmquist index }\end{array}$ & $1980-2000$ \\
\hline $\begin{array}{l}\text { Vergara and Rivero } \\
(2006)\end{array}$ & Chile & $\begin{array}{c}\text { National } \\
\text { Accounts, INE }\end{array}$ & Agriculture & $5.92 \%$ & Production Function & 1996-2001 \\
\hline $\begin{array}{l}\text { Dias and Evenson } \\
(2010)\end{array}$ & $\begin{array}{c}\text { Chile } \\
\text { (78 countries) }\end{array}$ & FAO & Agriculture & $1.37 \%$ & Accounting ratio & $1961-2001$ \\
\hline $\begin{array}{l}\text { Headey, Alauddin and } \\
\text { Rao (2010) }\end{array}$ & $\begin{array}{c}\text { Chile } \\
\text { (88 countries) }\end{array}$ & FAO & Agriculture & $\begin{array}{l}1.10 \% \\
2.7 \%\end{array}$ & Production Function & $\begin{array}{l}1970-1985 \\
1986-2001\end{array}$ \\
\hline $\begin{array}{l}\text { Nin-Pratt and Yu } \\
(2010)\end{array}$ & $\begin{array}{c}\text { Chile } \\
\text { (63 countries) }\end{array}$ & FAO & Agriculture & $2.20 \%$ & $\begin{array}{l}\text { Non-parametric } \\
\text { Malmquist index }\end{array}$ & $1967-2006$ \\
\hline $\begin{array}{l}\text { Astorga, Bergés and } \\
\text { Fitzgerald (2011) }\end{array}$ & $\begin{array}{l}\text { Chile }(6 \\
\text { countries })\end{array}$ & OxLAD & Agriculture & $1.30 \%$ & $\begin{array}{c}\text { Value added per } \\
\text { head }\end{array}$ & $1900-2000$ \\
\hline $\begin{array}{l}\text { Lachaud, Bravo- } \\
\text { Ureta and Ludena } \\
\text { (2015) }\end{array}$ & $\begin{array}{c}\text { Chile } \\
\text { (112 countries) }\end{array}$ & FAO & Agriculture & $1.33 \%$ & $\begin{array}{c}\text { Production Frontier } \\
\text { with Climate } \\
\text { adjustment }\end{array}$ & $1961-2012$ \\
\hline Lema (2015) & $\begin{array}{c}\text { Chile } \\
(5 \text { countries })\end{array}$ & FAO & Agriculture & $2.48 \%$ & Accounting & $1961-2012$ \\
\hline $\begin{array}{l}\text { Trindade and } \\
\text { Fulginiti (2015) }\end{array}$ & $\begin{array}{l}\text { Chile }(10 \\
\text { countries) }\end{array}$ & FAO & Agriculture & $\begin{array}{l}2.55 \% \\
1.89 \%\end{array}$ & $\begin{array}{l}\text { Production Function } \\
\text { and Non-parametric } \\
\text { Malmquist index }\end{array}$ & 1969-2009 \\
\hline Nin et al. (2015) & $\begin{array}{c}\text { Chile } \\
\text { (134 countries) }\end{array}$ & FAO & Agriculture & $2.30 \%$ & $\begin{array}{l}\text { Production Function } \\
\text { and Non-parametric } \\
\text { Malmquist index }\end{array}$ & $1961-2012$ \\
\hline $\begin{array}{l}\text { Moreira and Bravo- } \\
\text { Ureta (2016) }\end{array}$ & $\begin{array}{l}\text { Biobío Region to } \\
\text { Los Lagos }\end{array}$ & CEGE Todoagro & Dairy & $\begin{array}{l}2.25 \% \\
2.57 \%\end{array}$ & $\begin{array}{c}\text { Stochastic } \\
\text { Production Frontier } \\
\text { Translog }\end{array}$ & $2005-2010$ \\
\hline $\begin{array}{l}\text { Lachaud, Bravo- } \\
\text { Ureta and Ludena } \\
\text { (2017) }\end{array}$ & $\begin{array}{c}\text { Chile } \\
\text { (28 countries) }\end{array}$ & FAO & Agriculture & $1.82 \%$ & $\begin{array}{l}\text { Production Frontier } \\
\text { with Climatic } \\
\text { Adjustment }\end{array}$ & 1961-2012 \\
\hline Riveros (2019) & Chile & $\begin{array}{l}\text { Central Bank, } \\
\text { INE }\end{array}$ & $\begin{array}{l}\text { Agriculture, } \\
\text { Forestry and } \\
\text { Fisheries }\end{array}$ & $1.10 \%$ & Growth Accounting & $1996-2018$ \\
\hline $\begin{array}{l}\text { Lachaud and Bravo- } \\
\text { Ureta }(2020)\end{array}$ & $\begin{array}{c}\text { Chile } \\
\text { (28 countries) }\end{array}$ & FAO & Agriculture & $2.20 \%$ & $\begin{array}{l}\text { Production Frontier } \\
\text { with Climatic } \\
\text { Adjustment }\end{array}$ & 1961-2014 \\
\hline Simple Average & -- & -- & -- & $1.90 \%$ & -- & -- \\
\hline
\end{tabular}


the second study centering only on Chile, employ aggregate data and estimate the TFP of different sectors, including agriculture. The study reports a $5.92 \%$ TFPC, and this is the highest estimate included in Table 2. Moreira and Bravo-Ureta (2016) use micro data from a sample of dairy farms from southern Chile for the period 2005-2010 and estimate annual TFPC varying from $2.25 \%$ to $2.57 \%$. An analysis of TFPC components reveals that technological change is the most important contributor to productivity growth.

Fulginiti and Perrin (1997) use a nonparametric Malmquist index, with FAO information including Chile along with 18 other countries, for the period 1961-1985. A salient result of the study is that at least half of the countries experienced a decrease in productivity, except for Chile, which enjoyed an average annual TFPC gain of $1.1 \%$. In an extension of the previous paper, Fulginiti and Perrin (1998) estimate alternative Cobb Douglas specifications and find the same TFPC as the previous study. Arnade (1998) use a DEA nonparametric Malmquist index, with FAO and USDA information for the period 1961-1993 for 70 countries, which corresponds with the period of the green revolution. This study reports a TFPC of $1.25 \%$ and finds that education, research and extension were important contributors.

Martin and Mitra (2001) analyze and compare TFP between the agricultural and manufacturing sectors. Fifty countries of different income levels are included for the 1967-1992 period. Cobb-Douglas and translog production functions are used along with data from the FAO, World Bank and OECD. The TFPCs reported for the agricultural sector are $2.70 \%$ and $2.73 \%$ for the translog and Cobb-Douglas functional forms, respectively. Bravo-Ortega and Lederman (2004) apply a methodology similar to that of Martin and Mitra and utilize FAO data for 70 countries. The average TFPC for the period 1960 to 1997 is $1.20 \%$.

Nin, Arndt and Preckel (2003) use a Malmquist nonparametric approach and report an annual TFPC of $0.6 \%$ between 1961 and 1994. In a related paper, Nin et al. (2003) estimate distance functions and calculate Malmquist indices over the 1965-1994 period. The TFPC values reported for Chile are as follows: agriculture $0.87 \%$, cattle $0.82 \%$, and crops $2.25 \%$. Both papers use FAO data. Trueblood and Coggins (2003) utilize a larger FAO dataset than the previous authors, including 115 countries for the period 1961-1991. A Malmquist index is applied, and the reported TFPC for Chilean agriculture is $1.39 \%$. Lema (2015) relies on FAO and World Bank data for five countries for the period 1961-2012 and observes that Chile's TFPC was $2.48 \%$. Rao and Coelli (2004) include 97 countries from the FAO dataset from 1980 to 1995 along with DEA to estimate a two-output distance function, considering livestock and crops, which they use to calculate Malmquist TFP indices. These authors report an annual TFPC of $1.9 \%$. In an extension of the previous study, Coelli and Rao (2005) cover 93 countries for 1980-2000 and report a TFPC of $1.1 \%$.

Astorga, Bergés and Fitzgerald (2011) analyze 100 years of data (1900-2000) from OxLAD and measure TFPC as the variation in value added per inhabitant. They report an annual change of $1.3 \%$ in Chile's productivity. The study identifies three statistically distinct periods (1900-36, 1933-77, and 1978-2000), with substantial and sustained productivity growth in 1933-77. Dias and Evenson (2010) use FAO data for 78 countries and report a TFPC of $1.37 \%$ from 1961 to 2001. Headey, Alauddin and Rao (2010) investigate TFP employing SPF and DEA and examine the correlation between institutional and policy variables and TFP. This study uses FAO data for 88 countries for two different periods, 1970-1985 and 1986-2001, and reports TFPC values of 1.1\% and $2.7 \%$, respectively. Nin-Pratt and $\mathrm{Yu}$ (2010), using FAO data for 63 countries and a nonparametric Malmquist index, report an annual TFPC of $2.2 \%$ for 1967 to 2006 .

Trindade and Fulginiti (2015) analyze the productivity of 10 South American countries again 
using FAO data along with SPF and nonparametric models, and the TFPC for Chile is $2.55 \%$ and $1.89 \%$ according to each method. Chile is the best performing country of all those included in the study. Nin et al. (2015) study the TFP of 134 countries with FAO data for the period 1961 to 2012. They employ nonparametric Malmquist indices and production functions and find a TFPC value of 2.3\%. Lachaud, Bravo-Ureta and Ludena (2015) also study the TFP of Latin American and Caribbean (LAC) countries and make comparisons with other regions of the world relying on FAO data from 1961 to 2012. The authors estimate SPF models, incorporating climatic variables, and use the TFP decomposition proposed by O'Donnell (2014). A $1.33 \%$ TFPC for Chilean agriculture is reported.

The recent study by Lachaud, Bravo-Ureta and Ludena (2017) applies a more refined methodology than the one used in their 2015 paper to analyze the TFP of 28 LAC countries with FAO data for the period 1961-2012. The results show that climatic variability has had negative productivity effects in most of the LAC countries analyzed, and such effects have been more severe in Central America. The authors report a TFPC of $1.82 \%$ for Chilean agriculture. Riveros (2019) uses data from the Chilean Central Bank and INE covering agriculture, forestry and fisheries for the period 1996-2018 along with a growth accounting approach and finds a TFPC of $1.1 \%$. Lachaud and Bravo-Ureta (2020) extend their previous work to examine catch-up and convergence patterns incorporating climatic effects and report a TFPC of $2.2 \%$ for Chilean agriculture. ${ }^{1}$

The studies presented in Table 2 and reviewed above reveal an overall annual average TFPC for Chile of $1.90 \%$. This performance compares well to that of many countries around the world, particularly with LAC countries. A key point to note is that most of the available evidence comes from macrolevel studies, which makes it impossible to examine in detail the heterogeneity that characterizes agriculture within a country across many dimensions, including types of production, technological level, farm size, land tenure, socioeconomic features, location, agroecological characteristics, and environmental conditions, among others. In addition, to provide robust measures of TFP growth and to then decompose these measures into its various elements, panel data are critical but, unfortunately, limited.

In sum, to account for the heterogeneity of agricultural producers, analysts require detailed farmlevel data. However, our overview of the Chilean productivity literature clearly reveals that this type of information is scant. Moreover, to derive robust TFPC measures that can be separated into various components and thus generate the insights needed for evidence-based policy formulation and implementation, we need not only farm-level data but also a panel structure and consistent data collection over time. Preliminary evidence of the vastly different productivity measures that can be obtained when using macro/country versus micro/ farm data is provided by Bravo-Ureta et al. (2021) for El Salvador. Moreover, the Salvadorean farmlevel analysis reveals considerable heterogeneity over time and across different geographies and farm types. The bottom line is that consistent high-quality farm-level panel data are essential in uncovering robust productivity patterns that in turn can be used to derive robust policy recommendations.

\section{Agricultural productivity statistics for Chile}

This section first provides a summary of the basic variables that are needed to measure agricultural

\footnotetext{
1 The USDA-Economic Research Service International Agricultural Productivity Accounts also provide TFP measures for Chilean agriculture, beginning in 1961 and updated periodically. The current online version of the dataset covers 1961 to 2016. For additional information the interested reader can go to https://www.ers.usda.gov/data-products/international-agricultural-productivity/.
} 
productivity. This summary is followed by an overview of the system currently used in Chile to generate agricultural production data and then a discussion of the crucial shortcomings that need to be addressed as we move forward.

\section{Variables: outputs, inputs, other}

A point of departure in developing robust productivity measures is a sharp definition of outputs, inputs, and other complementary variables. Agricultural output variables commonly used in efficiency and productivity studies include the physical output of annual and perennial crops, livestock and dairy production, total value of farm production and corresponding prices (Bravo-Ureta et al., 2017).

The input variables used to measure agricultural productivity are numerous, and here, we rely on various sources to classify inputs along six dimensions (Bravo-Ureta et al., 2017; GSARS, 2017; Shumway et al., 2016). The first dimension corresponds to classic inputs and includes land, family and hired labor, seeds, chemical inputs (e.g., fertilizers, pesticides, fungicides), and water. This dimension also includes machinery, animal traction, fuel, and electricity.

The second dimension consists of environmental variables, and this can be divided into intrafarm (e.g., soil types and quality, slope) and extrafarm (e.g., climate, rainfall, temperature, altitude) variables. This dimension has gained considerable importance, as reflected by efforts from the OECD to create an international network on agricultural total factor productivity and the environment with the goal of developing "environmentally adjusted" TFP (EATFP) indicators across countries. More generally, this initiative has documented the existing data heterogeneity and the dearth of input, output and environmental variables that are required to develop robust and consistent EATFP indicators. A concern is that omitting environmental effects can be a source of systematic bias in productivity estimates and thus lead to misguided policy formulation (Sauer \& Moreddu, 2020).

The third dimension captures the agricultural system (e.g., technological level, irrigation systems, conservation practices, crop rotations, conventional versus organic production, cooling systems). The fourth category is the human and social capital dimension (e.g., education, gender, age, experience, and ethnicity of the farmer; family size and composition; social networks). The fifth dimension corresponds to financial capital, such as access to credit, subsidies, and public/private incentives. Six dimensions are devoted to specific livestock operations, including variables such as feed, herd (flock) size, and veterinary and medical expenses.

The list of dimensions and corresponding variables is not intended to be exhaustive. The idea is to highlight that farming is heterogeneous. This diversity and complexity must be kept in mind and fully understood when designing protocols to gather the information required to undertake robust measurement and analysis of farm productivity.

An important and expanding effort is the Guide for the Integrated Agricultural Survey (AGRIS), sponsored by the Food and Agriculture Organization (FAO). The goal is to provide an international framework to improve data collection systems and statistics in four main areas: production units; crop and livestock production; cost of production; and national accounts for agriculture. AGRIS encourages countries to generate open access and low-cost statistics using the best available technologies for data collection. The statistics generated by the AGRIS platform are intended to support policy formulation, market efficiency improvements, and research. A vital consideration is to assist governments in the development of economic, social and environmental models and indicators to document the evolution of the Sustainable Development Goals (SDGs) agenda (GSARS, 2018).

The AGRIS platform incorporates farm-level microdata and aggregates secondary data, 
including national agricultural accounts based partially on administrative data for the value of imports, exports, and taxes. GSARS (2017) proposes a core module to gather data annually or more often depending on the product, capturing the volume of agricultural production and inputs used at the farm level. The core module is complemented with data collected with the following four rotatory modules: Economy; Labor; Production Methods and the Environment; and Machinery, Equipment and Other Assets. Table 3 shows the AGRIS modules and some details concerning the subject, section, and data collection frequency.

\section{Agricultural data collection in Chile}

The National Institute of Statistics (INE for its acronym in Spanish) is the Chilean entity responsible for collecting official statistics, including the agricultural sector. The Office of Agricultural Studies and Policies (ODEPA for its acronym in Spanish), under the Ministry of Agriculture,

Table 3. AGRIS Modules, and data collection frequency.

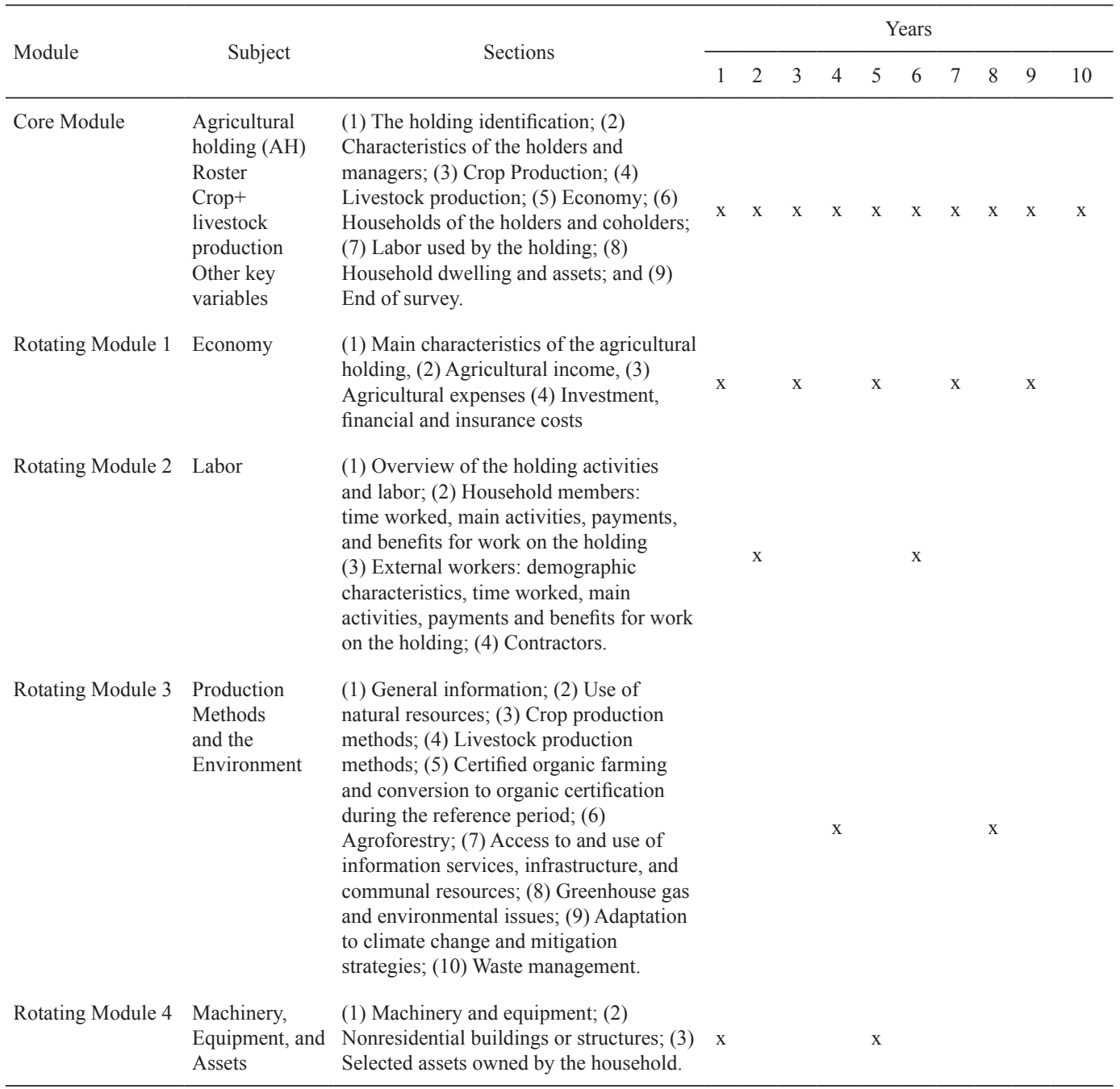

Source: Elaborated by the authors based on GSARS (2017). 
is the agency charged with providing statistical information for the farm sector that can be used by public and private agents for decision-making and related activities (Law 19,147). The ODEPA has a coordinating role in the national agricultural statistical system and in interinstitutional agreements with the INE that seek to provide official information. The Natural Resources Information Center (CIREN for its acronym in Spanish) is another agency of the Ministry of Agriculture and focuses mainly on gathering information for the fruit subsector, agroindustry, and biophysical characteristics of the territory.

According to INE (2015), there is a growing demand for statistical information by different stakeholders, which provides an impetus to improve the data collected and the methodologies utilized. The data currently collected and analyzed by the ODEPA with bearing on productivity measurement and monitoring include: A) annual surveys; B) Fruit Cadaster; and C) the National Agricultural and Forestry Census.

A) Annual surveys are focused on the following subsectors: industrial crops, vegetables, and livestock production. Industrial crops and vegetable surveys, administered annually by the INE, are designed based on a list sampling frame derived from Census information. Data for output quantities are collected exclusively for industrial crops. For livestock surveys, the INE also uses a list sampling frame, and every two years, it gathers information on herd size and on farm management and some sustainability practices. The information for all subsectors has national coverage and regional representation, except for regions where the specific output is not significant. The data collected annually are not uniform across subsectors, and this unfortunate feature restricts the scope of the economic analyses that can be performed. In the case of productivity, only single input measures can be generated for industrial crops. Another limitation of all these annual surveys is the absence of questions regarding intermediate inputs, labor, capital, and management practices.
In addition, the micro (farm level) data collected are not available to researchers or other interested individuals, which precludes the undertaking of any type of econometric analysis.

B) The Fruit Cadaster, implemented by the CIREN and funded by the ODEPA, is a yearly survey conducted in specific regions of the country. The survey is applied according to a schedule set by the ODEPA, which usually rotates in two- to three-year intervals for each region. For example, in 2017 and 2019, this cadaster was implemented in the Metropolitan and Valparaíso regions. In 2016 and 2019, the following eight regions were covered: Arica and Parinacota, Tarapacá, Maule, Biobío, La Araucanía, Los Ríos, Los Lagos, and Aysén. In 2016, Aysén was incorporated into the cadaster for the first time due to the increasing planting of cherry trees, while Arica and Parinacota and Tarapacá, in northern Chile, were surveyed for the first time in 30 years. The cadaster is considered a census of all farms with 0.5 or more hectares devoted to fruit production. The variables available from the cadasters include geographical location, producer identification, name of the species and variety grown, area by plot, and total hectares planted. As a complement to the fruit-growing cadaster, the CIREN has implemented the Fruit Infrastructure Cadaster since 2014. This includes owner information, geographical location, cold storage facilities, packing plant installations, fumigation machinery, and infrastructure. As is the case with the annual surveys, the cadasters omit variables that are indispensable to measure TFP and to undertake related economic analyses, such as quantity produced and the quantities and type of labor, capital, and intermediate inputs used.

C) The National Agricultural and Forestry Census is a source of statistical data collected approximately every 10 years with the objective of characterizing the agricultural, livestock and forestry dimensions of the sector. An important application is upgrading the statistical frame for annual surveys and to identify and measure various attributes concerning production, land 
tenure, employment, and socioeconomic features of the farms. The last census conducted in 2007 also included technological variables (e.g., irrigation system) and the adoption of best management practices (INE, 2015). The data are available at the municipality level and are suitable to measure partial productivity indicators. Again, the lack of detailed information for intermediate inputs, labor and capital impedes work on TFP. The National Agricultural and Forestry Census 2020 excludes output information, which restricts the measurement even of partial productivity indicators.

Agricultural statistics can also be obtained from a few private organizations that operate in Chile, such as the Consorcio Lechero (Dairy Consortium), which has a benchmarking system that includes technical and economic information for dairy farms. Another source of data for the dairy sector is the International Farm Comparison Network (IFCN), which collects synthetic information for representative dairy farms prepared by participating institutions throughout a number of countries (https://ifcndairy.org). Chile has been an IFCN participant since 2003. The data are not available to the public but can be used in collaboration with participating institutions. An advantage of these data is the detailed inclusion of inputs (e.g., different types of feed, land, labor, capital) and the availability of repeated observations over time. Thus, single factor and TFP indicators could be calculated for individual countries, while econometric models could be estimated by pooling the data for different countries, which would allow deeper production economic analyses.

Another international network that generates data similarly to the IFCN is Agri benchmark (http://www.agribenchmark.org/horticulture. html) sponsored by the Thünen Institute of Farm Economics in Germany. This network includes agricultural economists, consultants and producers who collaborate in the generation of comparable quantitative information for several sustainable production systems and countries. Agri bench- mark uses a representative farm-level approach to develop variable costs of production separated into various input classes, such as seeds, fertilizers, pesticides, labor (hired and family), land area and tenure, irrigation, rainfall distribution, soil type, land prices, capital assets, fixed costs, and subsidies (Chibanda et al., 2020).

\section{Agricultural Data Systems: Examples from Australia and the United States}

This section considers salient features of the agricultural information systems that are currently used in Australia and the United States. The purpose is to glean ideas that could help formulate policies to strengthen the Chilean statistics framework and thus generate data that could be used to develop solid measures of farm productivity applicable for research and policy formulation.

The Australian Bureau of Statistics (ABS) and the Australian Bureau of Agricultural and Resource Economics and Sciences (ABARES)

In 2014, ABS and ABARES (2014) developed a strategy to guide and coordinate long-term actions to improve the agricultural statistical system housed at the National Agricultural Statistics Review (NASR). The strategy recommended shifting from a direct data collection system based on surveys to one that relies on administrative information generated from business operational records. The aim was to improve accuracy, reduce costs and lessen the burden imposed on information providers. The strategy, named Roadmap to Improve the Agricultural Statistical System, sought to transform the information system and enhance its value to stakeholders while facilitating research, policy design and decision-making (ABS, 2017).

The new components of the Australian agricultural statistics architecture are aligned with the 
strengthening of public and private data collection efforts to reduce coordination challenges; the inclusion of novel sources of information, mainly from administrative data; and the application of alternative data collection sources, such as big data, satellite images, industry reports, and management software. Likewise, incorporating private stakeholders in the agricultural data collection process is crucial for detecting the multiplicity of information needs across different agricultural value chains (ABS, 2017).

Hughes et al. (2020) argue that combining the work undertaken by the ABS and ABARES is necessary to analyze, develop and integrate new longitudinal datasets at the farm level, an initiative called the Agricultural Data Integration Project (AgDIP). This project could be a particularly relevant reference for redesigning and implementing a more robust agricultural statistical system in Chile.

The USDA and the Economic Research Service (ERS)

The agricultural statistical system sponsored by the Economic Research Service (ERS) at the United States Department of Agriculture (USDA) is one of the most developed systems in the world, generating various products that provide a rich information base for individual and aggregate outputs (GSARS, 2017). This system is continually evolving through interactions with cutting-edge researchers and practitioners from public and private organizations, including universities and extension services. These interactions have allowed continuous improvements through ongoing reviews of the methods and data necessary to undertake a wide range of analyses (Shumway et al., 2016). The desired outcome is a modern agricultural system driven by high-quality data and analyses that substantiate well-articulated public policies while upholding carefully crafted confidentiality principles (Commission on Evidence-Based Policymaking, 2017).
Productivity measures at the state level have been an essential component underpinning US agricultural policy for decades (e.g., Ball et al., 1999; Ball, Hallahan, \& Nehring, 2004). However, in 2004, the National Agricultural Statistical Service (NASS) discontinued the farm labor survey, a key component used to construct the labor input. The lack of a suitable alternative to the farm labor survey means that the ERS TFP state-level series ends in 2004. The expectation is that a suitable alternative for constructing the labor input will be found and that the ERS TFP state-level series will be reintroduced (Shumway et al., 2016). Meanwhile, the ERS continues to update the national-level TFP series biennially. Except for the lack of an appropriate alternative to the farm labor survey, the existing information for both outputs and inputs remains useful for productivity analysis.

Another critical element in the USDA farm data infrastructure is the Agricultural Census, which dates to 1840 as part of the federal census. It was initially conducted every 10 years up to the 1950s and then every four years up to 1982 . The Agricultural Census is currently implemented every five years, with 2017 being the most recent census year (Powell, 2019). "The agriculture census is the only source of statistics on American agriculture showing comparable data, by county and classifying farms by size, tenure, type of organization, primary occupation, age of operator, market value of agricultural products sold, combined government payments and market value of agricultural products sold, and North American Industry Classification System (NAICS) code" (USDA, 2011, p. 4).

The Agricultural Census data are used regularly by the USDA to prepare a wide-ranging set of reports. The data at the county level can be accessed readily online by individuals not associated with the USDA (USDA, 2021a). These data have been used in scholarly articles by several authors, including Njuki and Bravo-Ureta (2018), Key (2019), and Sneeringer and Key (2011). 
An additional important data component sponsored by the USDA-ERS and NASS is the Agricultural Resource Management Survey (ARMS). The ARMS survey is based on a multi-frame, stratified, and probability weighted sampling design, and the data collection considers a multiphase scheme. The ARMS statistical design uses area and list sampling frames to sample a total of approximately 30,000 farms and ranching operations each year from across the 48 contiguous states using a stratification that includes groups of farms by region or state, farm sales categories, and commodity specialization. Given that the ARMS survey is a stratified random sample, each observation has a different weight reflecting the probability of farm selection (ERS, 2020). Data collection on management practices, farm business structure and finance, and household characteristics is undertaken in three phases: (1) The year of data collection (usually in the summer) farmers are randomly selected and contacted to verify their production status; (2) During the following winter, a random sample from the farmers in phase 1 is interviewed regarding production practices and input use; and (3) In early spring, the farmers in phase 2 are interviewed to collect additional financial data (ERS, 2020).

ARMS data for single or multiple survey years are used extensively to investigate a variety of topics, including production, cost and financial analyses for several commodities, such as industrial crops, fruits, dairy, livestock, and poultry. A detailed explanation of the suite of reports prepared by the ERS based on the ARMS data is available in MacDonald (2019), and a catalog of publications that rely on ARMS data can be found in USDA (2021b).

ARMS data are also employed regularly to prepare journal articles. An example of this is a recent paper by McFadden, Rosburg, and Njuki (2021), who focused on the connection between the use of yield and soil map data and the productivity of corn farming in the US Midwest. Another article dealing with corn production was published by Wechsler and Smith (2018). Sabasi, Shumway, and Astill (2019), Key and Sneeringer (2014), and Mosheim and Lovell (2009) published articles focusing on different aspects of dairy farm productivity. Claassen, Duquette, and Smith (2018) use ARMS data to examine the possible additionality of conservation programs over the period 2009-2012 for various crops.

In summary, the USDA-ERS has a multilayered information system including the farm, county, state and national levels, and the associated datasets are used to generate several informational, research and policy products. The data generated by the USDA are also complemented by surveys conducted by other agencies that provide information on a variety of indicators related to the overall population, consumers, the labor force, market input and output prices and price indices. These data provide the critical ingredients required to generate the USDA agricultural TFP indices and to inform policymaking.

\section{Recent Developments ${ }^{2}$}

Before moving to the conclusion, it is important to mention the 2021 World Development Report and the $50 \times 2030$ Initiative. The World Bank (2021b) Report, entitled Data for Better Lives, provides a comprehensive analysis of challenges and opportunities associated with data generation, utilization, and governance. A core issue of the report is "(h)ow to turn data into information and information into insights that can help the poor...." (p. 24, World Bank, 2021b). The report

\footnotetext{
2 Although it is not a recent development, we need to mention the Living Standards Measurement Study (LSMS) conducted by the World Bank (2021a). This has been a significant effort devoted to collect farm household data in many countries around the world. Over the last decade, this work has focused on several African countries under the LSMS-ISA (Integrated Surveys on Agriculture) initiative.
} 
also highlights potential benefits that geographic information systems and remote sensing along with data analytics can have for farm management and the advancement of 'smart agriculture' while helping cope with production and financial risk. Several examples are mentioned to illustrate how information systems are being applied along different agricultural value chains in various developing countries. The issue of data protection and confidentiality is addressed at length in the report, with a full chapter devoted to data governance.

The $50 \times 2030$ Initiative (2021) has been generated as a cooperative effort between the International Fund for Agricultural Development (IFAD), the Food and Agriculture Organization (FAO) and the World Bank. This initiative is anchored on the notion that public policies and investment decisions needed to promote agriculture and reduce poverty must have an 'evidence-based foundation'. However, in many countries, the data required to develop such evidence are inadequate, and this information gap needs to be closed. Therefore, the $50 \times 2030$ Initiative “... aims to empower and support 50 low and lower middle-income countries (L/LMICs) to build strong national data systems that produce and use high-quality, timely agricultural survey data" (p. 4). The data to be collected will develop evidence for various Sustainable Development Goals, particularly for SDG2 (zero hunger), which is the key goal related to agriculture, and SDG 5 (gender equality).

\section{Concluding Remarks}

The specific objectives of this paper were to provide a broad discussion of crucial agricultural productivity measures and an overview of major related methodologies, summarize empirical evidence regarding technical efficiency (TE) and total factor productivity (TFP) in Chilean agriculture, discuss the main sources of agricultural data in Chile, and provide a summary of the good practices currently employed in Australia and the
United States that could serve as a model as Chile moves forward with changes to its agricultural statistics system.

\section{Moving forward with agricultural production statistics in Chile}

Our overview of the agricultural data systems in Australia and the United States reveals several practices that deserve attention. A critical contribution of an agricultural census is the ability to update the existing sample frame, which can then be used to guide the implementation of other agricultural surveys conducted between census years. In addition to updates in sampling frames and lists of farmers, the redesign of the Chilean agricultural statistical system must consider enriching the collection of data for outputs, capital, intermediate inputs, labor, and prices as well as other variables needed to investigate interactions between agricultural production, environmental features, and climate change. This information is essential to generate robust estimates and analyses of technical efficiency, total factor productivity and related economic studies that provide the basis for sound agricultural policy formulation, implementation and evaluation.

Considering that the Agricultural Census is carried out every 10 years (or more), the statistical foundation developed from a particular census progressively loses relevancy as the intercensal period progresses. At the present, there are no alternative data sources to address this shortcoming. One option to tackle this deficiency is the implementation of a rotating approach along the lines of the USDA ARMS. To this end, it would be desirable to evaluate the implementation of a list and area framework focusing on key outputs and/or farming systems designed to periodically capture the dynamism and heterogeneity of agricultural production across different geographical areas. As suggested by GSARS $(2017,2018)$, the statistical base should be complemented with administrative information gathered by various 
entities, and this information should be updated on a regular basis to ensure the usefulness of the data. An example in Chile is the livestock administrative registration undertaken by the Agricultural and Livestock Service (SAG for its acronym in Spanish), which could be used to update the statistical framework of dairy and livestock farming.

Another matter that deserves careful consideration is the design of annual surveys that collect detailed farm-level output and input data suitable for productivity analysis. The statistical system should be reinforced with climatic and environmental variables using big data and machine learning methods to assemble and organize information that is currently available but dispersed across numerous Chilean agencies. These comprehensive datasets are needed in the estimation of econometric and other types of models to generate robust productivity indicators and enhance the formulation of evidence-based sustainable farm policies. Once the new agricultural statistical system is implemented, aggregate-level information needs to be well documented and widely available in formats that are easy to manipulate and to merge with other datasets. Moreover, a mechanism needs to be designed so that the microdata can also be made accessible to researchers while strictly adhering to well-designed confidentiality protocols.

The case for the importance of good-quality agricultural data should be clear, yet the lack of such data in Chile and many other low- and middle-income countries is a matter of rising concern and attention. Several multilateral agencies are actively involved in efforts to strengthen the collection, analysis and dissemination of farm data, including the FAO, the World Bank, the OECD and, most recently, the $50 \times 2030$ Initiative. A potential silver lining is the digital revolution, which is opening exciting opportunities in the data collection arena. Despite these opportunities, there are challenges, including concerns that prevailing institutional and policy settings could be a hindrance as digital technologies become more prevalent in agricultural policy formulation (OECD, 2019).

Specific challenges have been identified associated with the generation of the cross-country FAOSTAT data, which have been widely used in research projects, as documented above (see Table 2). These data are collected through a set of annual questionnaires sent to countries around the world. A noteworthy problem comes from incomplete reporting, which limits the ability to produce consistent data. These partial and incomplete responses are attributed to various reasons, such as the complexity and length of the questionnaires, budget constraints, lack of adequately trained staff, confidentiality, the absence of uniform data collection systems across countries, and inconsistent country-level data collection efforts (Dubey \& Mane, 2013). These issues clearly constrain the development of harmonized international datasets that can be used to evaluate performance across time and space. The FAO has made modifications to address some of these problems and has published revised agricultural production data for the 1991-2013 period as part of an ongoing process (FAO, 2016). To take full advantage of panel datasets, such as FAOSTAT, it is essential that the information be collected systematically over time and across countries (or other units of observation). Unfortunately, data collection instruments and systems can vary over time, and it is not always possible to adjust the entire time series so that consistency is ensured.

A final point is the need for closer coordination and integration among Chilean organizations (e.g., INE, CIREN, ODEPA) as well as with the international agencies involved in data collection and management. The goal should be to make the best use of national and international resources to harmonize efforts and enhance the overall Chilean agricultural statistics system. A strategy that provides leadership and incentives to promote this deeper collaboration is needed to foster efficiencies and improvements in the quality of the data collection process. It seems 
reasonable to argue that the Ministry of Agriculture, through the work of the ODEPA, has the capacity to advance the required mechanisms so that a revamped agricultural statistics system can provide robust information to measure and monitor productivity and other performance indicators while ensuring recurrent updates of the databases. The end goal is to strengthen the process of designing, implementing, and evaluat- ing agricultural policies based on solid evidence at a reasonable cost.

\section{Acknowledgements}

The authors gratefully acknowledge the helpful comments from two anonymous reviewers and from Eric Njuki.

\section{Resumen}

B.E. Bravo-Ureta, R. Jara-Rojas, V.H. Moreira López, y P. Riveros Villegas. 2021. Desafíos para generar la información necesaria para medir productividad agrícola: lecciones desde Chile. Int. J. Agric. Nat. Resour. 126-148. La medición y el análisis de la productividad han motivado considerables trabajos teóricos y empíricos en las últimas décadas. Una evolución notable se ha visto en modelos de fronteras de producción estocásticas para datos de panel. Estos modelos han demostrado ser muy útiles en la medición y análisis de la Productividad Total de Factores (PTF) y sus componentes. Sin embargo, en América Latina y el Caribe este tipo de análisis es limitado y una razón probable es la escasez de datos adecuados. Este artículo examina el entorno que rodea la medición y análisis de la productividad en el sector agrícola chileno. Los objetivos específicos son: 1) Resumir los indicadores usados para medir la productividad agrícola y recientes avances metodológicos; (2) Presentar una visión general de estudios que reportan medidas de eficiencia técnica y PTF en Chile; 3) Examinar las principales fuentes de datos agrícolas disponibles en el país; y 4) Revisar características claves de los sistemas de datos agrícolas utilizados en Australia y Estados Unidos. El documento termina identificando posibles mejoras en el sistema de información que podrían fortalecer las mediciones y el monitoreo de la productividad en Chile. El análisis sugiere que el país necesita avances sustanciales en la recopilación y análisis de estadísticas agrícolas para desarrollar estudios de productividad. Esta línea de trabajo es un paso crítico para luego mejorar la competitividad y fomentar adaptaciones al cambio climático, así como para participar plenamente en los esfuerzos patrocinados por el FIDA, FAO y la OCDE para monitorear el progreso de los Objetivos de Desarrollo Sostenible. Afortunadamente, la literatura ofrece diferentes opciones para progresar hacia una estructura estadística agrícola más robusta.

Palabras clave: Chile, eficiencia técnica, productividad total de los factores, sistema de datos. agrícolas.

\section{References}

ABS, Australian Bureau of Statistics. (2017). Roadmap to improve the agricultural statistics system. Australian Goverment, Department of Agriculture and Water Resources.
ABS, Australian Bureau of Statistics, \& ABARES, Australian Bureau of Agricultural and Resource Economics and Sciences. (2014). National Agricultural Statistics Review. Preliminary findings. Australian Bureau of Statistics (ABS). 
Ahmad, M., \& Bravo-Ureta, B.E. (1995). An econometric decomposition of dairy output growth. American Journal of Agricultural Economics, 77(4), 914-921. https://doi. org/10.2307/1243814.

Aigner, D.J., \& Chu, S.F. (1968). On estimating the industry production function. The American Economic Review, 58(4), 826-839. https://doi. org/10.2307/1926074.

Arnade, C. (1998). Using a programming approach to measure international agricultural efficiency and productivity. Journal of Agricultural Economics, 49(1), 67-84. https://doi. org/10.1111/j.1477-9552.1998.tb01252.x.

Astorga, P., Bergés, A.R., \& Fitzgerald, V. (2011). Productivity growth in Latin America over the long run. Review of Income and Wealth, 57(2), 203-223. https://doi.org/10.1111/j.1475-4991.2011.00447.x.

Ball, V.E., Gollop, F.M., Kelly-Hawke, A., \& Swinand, G.P. (1999). Patterns of state productivity growth in the U.S. farm sector: Linking state and aggregate models. American Journal of Agricultural Economics, 81(1), 164-179. https://doi. org/10.2307/1244458.

Ball, V.E., Hallahan, C., \& Nehring, R. (2004). Convergence of productivity: An analysis of the catch-up hypothesis within a panel of states. American Journal of Agricultural Economics, 86(5), 1315-1321. https://doi.org/10.1111/ j.0002-9092.2004.00683.x.

Bravo-Ortega, C., \& Lederman, D. (2004). Agricultural productivity and its determinants: Revisiting international experiences. Estudios de Economia, 31(2), 133-163.

Bravo-Ureta, B.E., Jara-Rojas, R., Lachaud, M.A., \& Moreira, V.H. (2017). A meta analysis of farm efficiency: Evidence from the production frontier literature. https://ageconsearch.umn.edu/ record/290067/.

Bravo-Ureta, B.E., Moreira, V.H., Troncoso, J.L., \& Wall, A. (2020). Plot-level technical efficiency accounting for farm-level effects: Evidence from Chilean wine grape producers. Agricultural Economics, 51(6), 811-824. https://doi.org/10.1111/ agec. 12593 .
Bravo-Ureta, B.E., Njuki, E., Salazar, L., \& Palacios, A. (2021). Agricultural productivity in El Salvador: A micro-econometric analysis. Working paper, ARE, University of Connecticut.

Bravo-Ureta, B.E., Solís, D., Moreira, V.H., Maripani, J.F., Thiam, A., \& Rivas, T.E. (2007). Technical efficiency in farming: A meta-regression analysis. Journal of Productivity Analysis, 27(1), 57-72. https://doi.org/10.1007/s11123-006-0025-3.

Chibanda, C., Agethen, K., Deblitz, C., Zimmer, Y., Almadani, M.I., Garming, H., Rohlmann, C., Schütte, J., Thobe, P., Verhaagh, M., Behrendt, L., Staub, D.T., \& Lasner, T. (2020). The typical farm approach and its application by the AGRI Benchmark Network. Agriculture, 10(12), 646. https://doi.org/10.3390/agriculture10120646.

Christensen, L.R. (1975). Concepts and measurement of agricultural productivity. American Journal of Agricultural Economics, 57(5), 910-915. https:// doi.org/10.2307/1239102.

Claassen, R., Duquette, E., \& Smith, D. (2018). Additionality in U.S. agricultural conservation programs. Land Economics, 94, 19-35. https://doi. org/10.3368/le.94.1.19.

Coelli, T.J., \& Rao, D.S.P. (2005). Total factor productivity growth in agriculture: A Malmquist index analysis of 93 countries, 1980-2000. Agricultural Economics, 32(s1), 115-134. https://doi. org/10.1111/j.0169-5150.2004.00018.x.

Coelli, T.J., Rao, D.S.P., O’Donnell, C.J., \& Battese, G.E. (2005). An introduction to efficiency and productivity analysis (2nd ed.). New York, USA: Springer. https://doi.org/0-387-25895-7.

Commission On evidence-bsed policymaking. (2017). The promise of evidence-based policymaking. Washington DC.

Cramon-Taubadel, S.V., \& Saldias, R. (2014). Access to credit and determinants of technical inefficiency of specialized smallholder farmers in Chile. Chilean Journal of Agricultural Research, 74(4), 413-420. https://doi.org/10.4067/S071858392014000400006.

Dias Avila, A.F., \& Evenson, R.E. (2010). Total factor productivity growth in agriculture: The role of technological capital. In P. Pingali \& 
R. Evenson (Eds.), Handbook of Agricultural Economics (Vol. Volume 4, pp. 3769-3822): Elsevier.

Dubey, S., \& Mane, E. (2013). Isues in the collection of FAO data. Food and Agriculture of the United Nations, AFCAS 23. http://www.fao. org/fileadmin/templates/ess/documents/afcas23/ Presentations/AFCAS_3f_Data_Collection_3 Dec_2013_copy.pdf.

ERS, Economic Research Service. (2020). ARMS documentation. United States Deparment of Agriculture (USDA).

FAO, Food and Agriculture of the United Nations. (2015). Food security and international trade: Unpacking disputed narratives. The state of agricultural commodity markets 2015-16 background paper. Rome, Italy.

FAO, Food and Agriculture of the United Nations. (2016). Revision of the agriculture production data domain in FAOSTAT. Rome: Food and Agriculture of the United Nations. http://fenixservices.fao.org/faostat/static/documents/Q/Q_Revision_Note_e.pdf.

FAO, Food and Agriculture of the United Nations. (2020). SDG indicator 2.4.1 proportion of agricultural area under productive and sustainable agriculture: Methodological note. Vol. Revision 10. Rome: Food and Agriculture of the United Nations.

Färe, R., Grosskopf, S., \& Margaritis, D. (2008). Efficiency and productivity: Malmquist and more. In H. O. Fried, C. A. K. Lovell, \& S. S. Schmidt (Eds.), The measurement of productive efficiency and productivity growth (pp. 638 p.): Oxford University Press US.

Filippini, M., \& Greene, W. (2016). Persistent and transient productive inefficiency: A maximum simulated likelihood approach. Journal of Productivity Analysis, 45(2), 187-196. https:/doi. org/10.1007/s11123-015-0446-y.

Fried, H.O., Lovell, C.A.K., \& Schmidt, S.S. (2008). The measurement of productive efficiency and productivity change. New York: Oxford University Press. https://doi.org/10.1093/acprof:o so/9780195183528.001.0001.

Fuglie, K., Gautam, M., Goyal, A., \& Maloney, W.F. (2020). Harvesting prosperity : Technology and productivity growth in agriculture. https://doi. org/10.1596/978-1-4648-1393-1.

Fulginiti, L.E., \& Perrin, R.K. (1997). LDC agriculture: Nonparametric Malmquist productivity indexes. Journal of Development Economics, 53(2), 373-390. https://doi.org/10.1016/S03043878(97)00022-9.

Fulginiti, L.E., \& Perrin, R.K. (1998). Agricultural productivity in developing countries. Agricultural Economics, 19(1-2), 45-51. https://doi. org/10.1016/S0169-5150(98)00045-0.

GSARS, Global Strategy to Improve Agricultural and Rural Statistics. (2017). Productivity and efficiency measurement in agriculture literature review and gaps analysis. Rome: Food and Agriculture of the United Nations.

GSARS, Global Strategy to Improve Agricultural and Rural Statistics. (2018). AGRIS handbook on agricultural integrated survey. Rome: Food and Agriculture of the United Nations.

Headey, D., Alauddin, M., \& Rao, D.S.P. (2010). Explaining agricultural productivity growth: An international perspective. Agricultural Economics, 41, 1-14. https://doi.org/10.1111/j.15740862.2009.00420.x.

Hughes, N., Gupta, M., Soh, W.Y., Boult, C., Lawson, K., Lu, M., \& Westwood, T. (2020). The agricultural data integration project. Australian Bureau of Agricultural and Resource Economics and Sciences, Research Report 20.21, December 2020. https://doi.org/10.25814/r8be-kt14.

INE, Instituto Nacional de Estadísticas. (2015). Estadísticas de superficie sembrada, producción y rendimiento. Instituto Nacional de Estadísticas. Chile.

Initiative, X. Producing, using, innovating: How $50 \times 2030$ is closing the agricultural data gap. June 2021, 50x2030 techical note series. (2021). Producing, using, innovating: How 50x2030 is closing the agricultural data gap. June 2021, 50x2030 techical note series.

Jaime, M.M., \& Salazar, C.A. (2011). Participation in organizations, technical efficiency and territorial differences: A study of small wheat farmers in Chile. Chilean Journal of Agricultural Research, 71(1), 104-113. https://doi.org/10.4067/ S0718-58392011000100013. 
Jaime, M.M., Salazar, C.A., \& Novoa, L.F. (2011). Participación y eficiencia técnica en la pequeña agricultura de la provincia de Ñuble (región del Bíobío, Chile). Horizontes Empresariales, 10(1), 9-20.

Jara-Rojas, R., Bravo-Ureta, B.E., Solis, D., \& Arriagada, D.M. (2018). Technical efficiency and marketing channels among small-scale farmers: Evidence for raspberry production in Chile. International Food and Agribusiness Management Review, 21(3), 351-364. https://doi. org/10.22434/IFAMR2016.0168.

Julien, J.C., Bravo-Ureta, B.E., \& Rada, N.E. (2019). Assessing farm performance by size in Malawi, Tanzania, and Uganda. Food Policy, 84, 153-164. https://doi.org/10.1016/j.foodpol.2018.03.016.

Key, N. (2019). Farm size and productivity growth in the United States corn belt. Food Policy, 84, 186-195. https://doi.org/10.1016/j.foodpol.2018.03.017.

Key, N., \& Sneeringer, S. (2014). Potential effects of climate change on the productivity of U.S. dairies. American Journal of Agricultural Economics, 96(4), 1136-1156. https://doi.org/10.1093/ajae/aau002.

Kumbhakar, S.C., \& Lovell, C.A.K. (2000). Stochastic frontier analysis. New York, USA: Cambridge University Press.

Lachaud, M.A., \& Bravo-Ureta, B.E. (2020). Agricultural productivity growth in Latin America and the Caribbean: An analysis of climatic effects, catch-up and convergence. Australian Journal of Agricultural and Resource Economics, forthcoming. https://doi.org/10.1111/14678489.12408

Lachaud, M.A., Bravo-Ureta, B.E., \& Ludena, C.E. (2015). Agricultural productivity growth in Latin America and the Caribbean and other world regions: An analysis of climatic effects, convergence and catch-up. Inter-American Development Bank, IDB Working Paper Series No IDBWP-607, Washington DC.

Lachaud, M.A., Bravo-Ureta, B.E., \& Ludena, C.E. (2017). Agricultural productivity in Latin America and the Caribbean in the presence of unobserved heterogeneity and climatic effects. Climatic Change, 143, 445-460. https://doi. org/10.1007/s10584-017-2013-1.
Lema, D. (2015). Crecimiento y productividad total de factores en la agricultura Argentina y países del cono sur 1961-2013. Serie de informes técnicos del Banco Mundial en Argentina, Paraguay y Uruguay $N^{\circ} 1,2015$.

MacDonald, J. (2019). Uses of ARMS data. ARMS phase III national workshop. https://www.youtube.com/watch?v=8jKuqSR7aYs.

Martin, J.P., \& Page, J.M., Jr. (1983). The impact of subsidies on $\mathrm{x}$-efficiency in LDC industry: Theory and an empirical test. The Review of Economics and Statistics, 65(4), 608-617. https://doi. org/10.2307/1935929.

Martin, W., \& Mitra, D. (2001). Productivity growth and convergence in agriculture versus manufacturing. Economic Development and Cultural Change, 49(2), 403-422. https://doi. org/10.1086/452509.

McFadden, J.R., Rosburg, A., \& Njuki, E. (2021). Information inputs and technical efficiency in Midwest corn production: Evidence from farmers' use of yield and soil maps. American Journal of Agricultural Economics, 1-24. https://doi. org/10.1111/ajae.12251.

Moreira L., V.H., Troncoso C., J.L., \& Bravo-Ureta, B.E. (2011). Technical efficiency for a sample of Chilean wine grape producers: A stochastic production frontier analysis. Ciencia e Investigación Agraria, 38(3), 321-329. https://doi. org/10.4067/S0718-16202011000300001.

Moreira, V.H., \& Bravo-Ureta, B.E. (2009). A study of dairy farm technical efficiency using meta-regression: An international perspective. Chilean Journal of Agricultural Research (former Agricultura Técnica), 69(2), 214-223. https://doi.org/10.4067/S071858392009000200011

Moreira, V.H., \& Bravo-Ureta, B.E. (2010). Technical efficiency and metatechnology ratios for dairy farms in three Southern cone countries: A stochastic meta-frontier model. Journal of Productivity Analysis, 33(1), 33-45. https://doi. org/10.1007/s11123-009-0144-8.

Moreira, V.H., \& Bravo-Ureta, B.E. (2016). Total factor productivity change in dairy farming: Empirical evidence from Southern Chile. Journal of 
Dairy Science, 99(10), 8356-8364. https://doi. org/10.3168/jds.2016-11055.

Moreira, V.H., Bravo-Ureta, B.E., Carrillo, B.L., \& Vásquez, J.A. (2006). Technical efficiency measures for small dairy farms in Southern Chile: A stochastic frontier analysis with unbalanced panel data. Archivos de Medicina Veterinaria, 38(1), 25-32. https://doi.org/10.4067/S0301732X2006000100004.

Morrison Paul, C.J. (1999). Scale economy measures and subequilibrium impacts. Journal of Productivity Analysis, 11(1), 55-66. https://doi. org/10.1023/A:1007783305190.

Mosheim, R., \& Lovell, C.A.K. (2009). Scale economies and inefficiency of U.S. dairy farms. American Journal of Agricultural Economics, 91(3), 777-794. https://doi.org/10.1111/j.14678276.2009.01269.x.

Nin-Pratt, A., Falconi, C., Ludena, C.E., \& Martel, P. (2015). Productivity and the performance of agriculture in Latin America and the Caribbean. IDB Working Papers Serie $N^{\circ} 608$.

Nin-Pratt, A., \& Yu, B. (2010). Getting implicit shadow prices right for the estimation of the Malmquist index: The case of agricultural total factor productivity in developing countries. $\mathrm{Ag}$ ricultural Economics, 41(3-4), 349-360. https:// doi.org/10.1111/j.1574-0862.2010.00446.x.

Nin, A., Arndt, C., Hertel, T.W., \& Preckel, P.V. (2003). Bridging the gap between partial and total factor productivity measures using directional distance functions. American Journal of Agricultural Economics, 85(4), 928-942. https://doi. org/10.1111/1467-8276.00498.

Nin, A., Arndt, C., \& Preckel, P.V. (2003). Is agricultural productivity in developing countries really shrinking? New evidence using a modified nonparametric approach. Journal of Development Economics, 71, 395-415. https://doi. org/10.1016/S0304-3878(03)00034-8.

Nishimizu, M., \& Page, J.M., Jr. (1982). Total factor productivity growth, technological progress and technical efficiency change: Dimensions of productivity change in Yugoslavia, 1965-78. Economic Journal, 92(368), 920-936. https:// doi.org/10.2307/2232675.
Njuki, E., \& Bravo-Ureta, B.E. (2018). Irrigation water use and technical efficiencies: Accounting for technological and environmental heterogeneity in U.S. agriculture using random parameters. Water resources and economics, 24, 1-12. https://doi.org/10.1016/j.wre.2018.02.004.

Njuki, E., \& Bravo-Ureta, B.E. (2019). Examining irrigation productivity in U.S. agriculture using a single-factor approach. Journal of Productivity Analysis, 51(2), 125-136. https://doi. org/10.1007/s11123-019-00552-x.

Njuki, E., Bravo-Ureta, B.E., \& Cabrera, V.E. (2020). Climatic effects and total factor productivity: Econometric evidence for Wisconsin dairy farms. European Review of Agricultural Economics, 47(3), 1276-1301. https://doi. org/10.1093/erae/jbz046.

Njuki, E., Bravo-Ureta, B.E., \& O’Donnell, C.J. (2018). A new look at the decomposition of agricultural productivity growth incorporating weather effects. PLOS ONE, 13(2), e0192432. https://doi.org/10.1371/journal.pone.0192432.

O’Donnell, C.J. (2014). Technologies, markets and behaviour: Some implications for estimating efficiency and productivity change. Paper presented at the 58th Annual Conference of the Australian Agricultural and Resource Economics Society, Port Macquarie.

O’Donnell, C.J. (2016). Using information about technologies, markets and firm behaviour to decompose a proper productivity index. Journal of Econometrics, 190(2), 328-340. https://doi. org/10.1016/j.jeconom.2015.06.009.

O’Donnell, C.J. (2018). Productivity and efficiency analysis: An economic approach to measuring and explaining managerial performance: Springer.

OECD, Organisation for Economic Cooperation and Development. (2019). Digital opportunities for better agricultural policies. https:/www.oecd-ilibrary.org/ sites/571a0812-en/index.html?itemId=/content/publication/571a0812-en.

Olavarría, J., Bravo-Ureta, B.E., \& Cocchi, H. (2004). Productividad total de los factores en la agricultura chilena: 1961-1996. Economía 
Agraria y Recursos Naturales, 4(8), 121-132. https://doi.org/10.22004/ag.econ.28774.

Powell, K. (2019). Agricultural schedules of the United States census. https://www.thoughtco. com/agricultural-schedules-united-states-census- 1422758 .

Rao, D.S.P., \& Coelli, T.J. (2004). Catch-up and convergence in global agricultural productivity. Indian Economic Review, 39(1), 123-148.

Rivas, T. (1996). Farm level technical efficiency in Chile: Another look at the agrarian reform process. (Master), University of Connecticut, Storrs, Connecticut, US.

Riveros, P. (2019). Evolución de la productividad silvoagropecuaria y una aproximación a sus determinantes. https://www.odepa.gob.cl/wp-content/uploads/2019/02/articulo-productividad201902.pdf.

Riveros, P., Aguirre, R., Ortega, J., \& Soto, S. (2016). La eficiencia técnica y una aproximación a sus determinantes: Una medida para mejorar la productividad en la fruticultura nacional. Oficina de Estudios y Políticas Agrarias, 26, 1-26.

Roco, L., Bravo-Ureta, B., Engler, A., \& Jara-Rojas, R. (2017). The impact of climatic change adaptation on agricultural productivity in Central Chile: A stochastic production frontier approach. Sustainability, 9(9), 1648. https://doi.org/10.3390/ su9091648.

Sabasi, D., Shumway, C.R., \& Astill, G.M. (2019). Off-farm work and technical efficiency on U.S. dairies. Agricultural Economics, 50(4), 379-393. https://doi.org/10.1111/agec.12497.

Santos, J., Foster, W., \& Ramírez, E. (2006). Estudio de la eficiencia técnica de productores de papa en Chile: El rol del programa de transferencia técnica de Indap. Economía Agraria, 10, 119-132. https://doi.org/10.22004/ag.econ.97362.

Sauer, J., \& Moreddu, C. (2020). Drivers of farm performance: Empirical country case studies. OECD Food, Agriculture and Fisheries Papers, No. 143, OECD Publishing, Paris. https://doi. org/10.1787/248380e9-en.

Shumway, C.R., Fraumeni, B.M., Fulginiti, L.E., Samuels, J.D., \& Stefanou, S.E. (2016). U.S. agricultural productivity: A review of USDA Economic Research Service methods. Applied
Economic Perspectives and Policy, 38(1), 1-29. https://doi.org/10.1093/aepp/ppv032.

Sickles, R.C., \& Zelenyuk, V. (2019). Measurement of productivity and efficiency: Theory and practice. Cambridge: Cambridge University Press. https://doi.org/10.1017/9781139565981.

Sneeringer, S., \& Key, N. (2011). Effects of sizebased environmental regulations: Evidence of regulatory avoidance. American Journal of Agricultural Economics, 93(4), 1189-1211. https:// doi.org/10.1093/ajae/aar040.

Triebs, T.P., \& Kumbhakar, S.C. (2018). Management in production: From unobserved to observed. Journal of Productivity Analysis, 49(2), 111-121. https://doi.org/10.1007/s11123-0180526-x.

Trindade, F.J., \& Fulginiti, L.E. (2015). Is there a slowdown in agricultural productivity growth in South America? Agricultural Economics, 46(S1), 69-81. https://doi.org/10.1111/agec.12199.

Trueblood, M.A., \& Coggins, J. (2003). Intercountry agricultural efficiency and productivity: A Malmquist index approach. World Bank.

UN, United Nations. (2016). The 2030 agenda and the sustainable development goals an opportunity for Latin America and the Caribbean. United Nations, ECLAC.

UN, United Nations. (2020). The sustainable development goals report 2020. United Nations.

USDA, United States Department of Agriculture. (2011). 2007 Census of Agriculture: History. Volume 2, subject series, part 7 ac-07-s-7.

USDA, United States Department of Agriculture. (2021a). Census of Agriculture. https://www. Nass.Usda.Gov/agcensus/.

USDA, United States Department of Agriculture. (2021b). Surveys. https://www.Nass.Usda.Gov/ surveys/guide_to_nass_surveys/ag_resource management/.

Veloso-Contreras, F., Cabas-Monje, J., VelascoFuenmayor, J., Vallejos-Cartes, R., \& Gil-Roig, J.M. (2015). Eficiencia técnica de los pequeños productores bovinos de la región centro sur de Chile. Revista Cientifica, FCV-LUZ, XXV(2): 99-106.

Vergara, R., \& Rivero, R. (2006). Productividad 
sectorial en Chile: 1986-2001. Cuadernos de Economía, 43, 143-168. https://doi.org/10.4067/ S0717-68212006000100005.

Wechsler, S., \& Smith, D. (2018). Has resistance taken root in U.S. corn fields? Demand for insect control. American Journal of Agricultural Economics, 100(4), 1136-1150. https://doi. org/10.1093/ajae/aay016.

World Bank. (2008). World Development Report: Agriculture for development. Washington DC.
World Bank. (2021a). The Living Standards Measurement Study (1SMS). The World Bank's flagship household survey progam since 1980. World Bank. https://www.worldbank.org/en/ programs/lsms.

World Bank. (2021b). World Development Report 2021: Data for better lives. World Bank. https:// doi.org/10.1596/978-1-4648-1600-0. 